[To cite this chapter: Freathy, R. and Parker, S. G. (2021). The Professionalization of Teachers of RE in England: A Case Study. In Simojoki, H.; Schweitzer, F.; Henningsen, J., and Mautz, J-R. (2020). Professionalisierung des Religionslehrerberufs. Analysen im Schnittfeld von Lehrerbildung, Professionswissen und Professionspolitik. Leiden: Brill | Schöningh. pp. 501-527.]

\title{
The professionalization of teachers of RE in England: a case study
}

\section{Rob Freathy and Stephen G. Parker}

\section{Introduction}

This chapter elucidates how one might investigate, describe and analyse the historical and institutional process of the professionalization of teachers of Religious Education (RE) in England between 1944 and 1988 as a basis for understanding past and present professionality and related discourses in the field. Little attention has been paid in the UK to the ways by which teachers of RE as a specific collective occupational body professionalized over time (Freathy et al 2014; Freathy et al 2016). More consideration has been given to 'individual professionalization' and conceptions of 'professionality'. We believe there may be a connection between past professionalization and present professionality in RE, and it is important to understand how particular conceptions of professionality emerged, and how historical and institutional processes affected the development and maintenance of professional characteristics and abilities. Knowledge of the past processes, policies and practices that helped or hindered the professionalization of teachers of RE has the potential to inform contemporary discussions about the structures, qualifications and curricula of initial and continuing forms of RE teacher education; the ways in which RE teachers are organized, governed and supported; and the conceptualisation, creation and dissemination of professional knowledge. Broader historical surveys of RE touch upon such matters, often in relation to the shortage of specialist teachers, and the insufficiency of initial and in-service RE teacher education, in the context of demonstrating the subject's poor status, position and funding (Copley 2008). These are significant issues, dominating the RE agenda for decades, especially in recent years (OFSTED 2013; REC 2013). Currently, the discrete subject of RE, where it exists, is often taught by unqualified teachers in Primary schools (5-11 year olds), and non-specialist teachers in Secondary schools (11-16/18 year olds) (APPG 2013,4). Even qualified RE specialists may lack relevant academic subject content knowledge (e.g. as acquired from Theology or Religious Studies degrees). Anxiety about the poor professional standing of RE teachers and teaching (Conroy 2013) has led to a number of initiatives to improve RE teaching, and the recruitment of specialist RE teachers. It is clear the professionalization of teachers of RE in England is a significant historical issue with contemporary relevance.

This chapter seeks to illustrate how the theoretical and methodological framework described in the preceding chapter could be applied to the English context to investigate the professionalization of teachers of RE conceptually and historically, taking account of characteristics and patterns of professionalization, and the factors that have shaped them (albeit recognising professionalization is not inevitable, homogeneous or irreversible). More specifically, following that framework, it seeks to be mindful of (i) the specialized and advanced academic education offered for teachers of RE by different types of institution and organization in various geographical locations; (ii) the multi-dimensional structure of professional knowledge as found especially in academic/professional journals; and (iii) the establishment of professional associations of/for teachers of RE, and the politics surrounding professional interests, especially the formative influence of state regulation and the instruments of faith and other stakeholders. It is presupposed that through these means, amidst other historical and institutional processes, teachers of RE assumed their specific shape and characteristics as an occupational group, leading to the development of particular understandings of such teachers as professionals. Although not underpinned by an empirically-based research project equivalent to that undertaken by the German research team, we hope the arguments and evidence presented will be sufficient to support the claim that the framework described in the preceding chapter does indeed have the potential to be a model for international comparison. Our report of its nascent implementation in the English context may act as a stepping-stone to subsequent and wider-ranging international comparative studies.

\section{Conceptual parameters}

There are similarities and differences between the processes of professionalization specific to teachers of RE and teachers more generally vis-à-vis, for example: recruitment and retention; initial and continuing professional development; subject knowledge requirements; competencies and standards; status and reputation; organizational structures; and power, agency, accountability and control. This is true for both primary and secondary school teachers. The extent to which teachers of RE should be deemed a specialist 
group of teachers, differentiated from the broader occupational body of teachers, depends on whether RE is conceived as a discrete and clearly delineated curriculum subject distinct from the rest of the curriculum and/or from religious education more broadly defined. If it is not so differentiated, then the teaching of RE is more likely to be undertaken by generalist teachers, and there may be less of a requirement for specialized knowledge and expertise, such as would be conferred by subject-specific initial and/or continuing professional education. This is why we describe our focus in terms of the professionalization of those who taught the curriculum subject of RE in primary and secondary schools, only insofar as professionalizing processes pertained to that subject and cognate dimensions of the teachers' work (i.e. religious education in a broader sense), and not to the professionalization of these teachers in their capacity as teachers in toto.

By 'teacher of RE' we mean those in English primary and secondary schools who taught the curriculum subject variously known as Scripture, Divinity, Religious Instruction, Religious Knowledge and Religious Education, but we do not ignore the complex and significant connections between RE and other curricular elements (e.g. Collective Worship), cross-curricular themes (e.g. spiritual and moral development), and the ethos and character of schools, where these impact upon the professionality and professionalization of teachers of RE. As we have shown previously (Parker et al 2016), for much of the twentieth century, RE was intimately connected to other elements of the curriculum, work and life of schools. In the 1944 Education Act, for example, 'religious education' referred to the combination of Collective Worship and the curriculum subject called Religious Instruction (RI). Prior to the Second World War, and in the period immediately afterwards, calls to professionalize religious education often focused on the application of a broader Christian philosophy to the nature and purpose of education and the nature of the child. On such occasions, 'religious education' was often used interchangeably, in a comprehensive and curricular sense, to refer respectively to (i) the religious nature of the educational process as a whole and through it the transmission of religious beliefs and values, and (ii) instruction in religion in the form of a curriculum subject (see Bates 1976). For this reason, the subject-specific notion of the professionalization of teachers of RE per se was often deemed part of a wider-ranging mission to professionalize all aspects of education concerned with, and/or grounded in, religion. It was largely from the 1960s that an increasing number of writers used the term Religious Education to refer to the curriculum subject only: a practice formalised by the 1988 Education Reform Act, which established a 'National Curriculum', consisting of three 'core' and six 'foundation' subjects, taught across four age-related Key Stages; as well as a separate 'Basic Curriculum', consisting solely of RE. Thereby, as the century progressed, RE in a curricular sense became increasingly differentiated from religious education in a comprehensive sense (Freathy 2005: 277; Parker 2015), and in certain respects remained consistently differentiated from the rest of the curriculum. For these reasons, it became more possible to conceive of teachers of RE as a distinct and specialised cadre of professional teachers, qualified by differentiated subject-specific knowledge and exclusive practical expertise, albeit recognising the continuously inadequate provision of RE in schools and of suitably qualified teachers thereof. In this chapter, the term religious education, in the lower case, encompasses Religious Instruction, Collective Worship and other religious elements of schooling, while the curriculum subject alone will be referred to as RI, RE or RI/RE, all in the upper case, and to reflect any significant historical particularity.

\section{Legal and political parameters}

Many of the unique features of the history of the professionalization of teachers of RE are associated with the subject's exceptional legislative framework which has distinctively shaped the aims, methods, contents and organizational structure of RE, and influenced national and local politics surrounding the professionalism, professionalization and professionality of teachers of RE in particular ways. This acts as a counter-point to generic conceptualisations and discourses of teacher professionalization, and justifies our subject-specificity.

Of the many distinctive arrangements for RE (see Doney, forthcoming), there are a couple worth highlighting. First, from the inception of state-funded elementary schools in 1870, there has been a 'dual system' of schools with and without religious affiliations. Between 1870 and 1944, in every public elementary school, in both sectors of the 'dual system', religious education (where provided) was undertaken in accordance with (i) a 'Conscience clause', which allowed parents to withdraw children from any religious observance or instruction, and from school on days set apart for religious observance by their denomination; and (ii) a 'Timetable clause', which limited provision of religious instruction or observance to the beginning or end of a school session to aid withdrawal. In one part of the 'dual system', Board schools (from 1870 until 1902), and then Local Education Authority (LEA) schools (from 1902 until 1944), were permitted to teach 
religion and usually did so, but there was no statutory obligation. In the same schools, religious education (where provided) was also constrained by the 'Cowper-Temple clause', which stated that no religious catechism or religious formulary which is distinctive of any particular denomination shall be taught. (From 1902, secondary schools established by LEAs were regulated by comparable conscience and timetable clauses.) In the other part of the 'dual system', so-called 'voluntary' schools, with religious affiliations, could teach denominationally-distinctive catechisms or formularies as part of their religious educational offering. This meant that - de jure if not de facto - there were potentially different forms of RE in these contrasting school sectors with concomitant implications for the professionalization of teachers of RE. For practicability, our primary focus is limited to the professionalization of teachers of RE in (i) LEA (formerly Board) schools without a religious affiliation, and (ii) Voluntary Aided, Voluntary Controlled and Special Agreement schools (as defined by the 1944 Education Act) with an affiliation to one of the Protestant churches only. (The often greater distinctiveness of RE in Catholic schools, as well as in the few Jewish schools, deserves separate and focused scrutiny.)

In terms of legislative jurisdiction and geographical parameters, we have focused solely on the professionalization of teachers of RE in England, where representatives of the officially-established Anglican Church play a statutory role in determining RE in both state-maintained schools without a religious affiliation and schools affiliated to the Church of England. Although the legal frameworks governing RE in England and Wales were aligned from 1944 to 1988, there is a distinction due to Church disestablishment in Wales earlier in the twentieth century. Nevertheless, we recognise that the professionalization of teachers of RE employed in schools within our geographically-, chronologically- and institutionally-defined sample may have been influenced by factors beyond the scope of our research, for example, initial and continuing professional development provided by higher education institutions outside of England and/or unaffiliated with the religious character of the schools in which they subsequently work (or indeed with their own faith perspectives).

Second, whilst principally known for introducing free secondary education for all 11-15 year olds, the 1944 Education Act also determined that all pupils, except those withdrawn by their parents, in all publicly-funded schools, should be provided with RI and daily Collective Worship. (RI/RE was the only curriculum subject schools were legally required to teach from 1944 until 1988.) The 1870 'Conscience' and 'Cowper-Temple' clauses were retained for relevant types of school, but the 'Timetable' clause was abolished for RI (not Collective Worship), so that the subject could be taught by specialists at any time of the day rather than by generalists simultaneously. To determine the subject's nature and purpose in LEA and Voluntary Controlled schools, LEAs had to devise or adopt a non-denominational Agreed Syllabus of RI, unanimously approved by a statutory local conference, consisting of four committees representing local religious denominations, the Church of England, teacher associations and the LEA. The idea of Agreed syllabuses originated in the interwar period to settle denominational and associated disputes, chiefly in the interests of furthering the development of secondary education (see, for example, County Council of the West Riding of Yorkshire: Education Department Syllabus of Religious Instruction, 1922; and The Cambridgeshire Syllabus of Religious Teaching for Schools, 1924). Although one of the committees constituting a local Agreed Syllabus Conference had to be comprised of representatives of teacher associations - having regard to local circumstances - there was no stipulation that these persons (or indeed those on any group) had to be teachers of RE. Thereby, de jure, teachers of RE had no rights with regard to the determination of the syllabuses according to which they had to teach the subject, even if de facto they were normally involved in these organizational processes, contributing to and benefitting from the resultant statutory regulations, and nonstatutory advice and guidance, as well as the associated collegial occupational relations and mutual support. The implications of their legal position, in terms of their professional standing and autonomy to determine professional knowledge, standards and expertise in the area they profess, were keenly felt until the 1988 Education Reform Act. This legislation resolved one anomaly, by making more subjects statutory, but exacerbated another, by legislating for the determination of these other subjects on a national basis rather than locally like RE. From 1988, the law articulated the scope of RE Agreed Syllabuses nationwide, as needing to reflect that religious traditions in Great Britain are in the main Christian, whilst taking account of the teaching and practices of the other principal religions represented in Great Britain. It also determined that Collective Worship in LEA schools should be wholly or mainly of a broadly Christian character, meaning it reflects the broad traditions of Christian belief without being distinctive of any particular Christian denomination. Nevertheless, the Standing Advisory Councils on Religious Education (SACRE), which LEAs had permission to establish following the 1944 Education Act to advise on all related matters, were now 
statutory requirements with a membership to reflect the constitution of Agreed Syllabus Conferences. Thus, whether at a national or local level, self-government and the leeway for independent self-interpretation by teachers of RE continued to be curtailed, not only by the internal structures and processes of the public service in which they were employed, which effect all teachers, but also by the involvement of particular external stakeholders, most notably the churches and other faith communities, in defining, governing and supporting religious education (Freathy et al 2016).

Having outlined some important conceptual, legal and political parameters, we can now apply the theoretical and methodological framework described in the preceding chapter to our study of the professionalization of teachers of RE in England within our selected chronological period.

\section{Initial and continuing professional development}

The professional expertise of teachers of RE results, wholly or partly, from the specialized and advanced knowledge acquired through initial and continuing teacher education, such as provided by universities, teacher training colleges, and other institutions, including those affiliated to faith communities. Analysis of such provision can include scrutiny of the curriculum and qualifications (examination regulations, certificates and awards, etc.) and their implications for professionality, albeit recognising that requirements and practices may vary over time, and from institution to institution, and that many materials were unpublished or only partially published. In the English context, analysis of initial and continuing professional development of teachers of RE can focus on: (i) different providers, including universities and teacher training colleges, with and without religious affiliations; (ii) different types of teacher education, including undergraduate degrees and postgraduate certificates/diplomas (e.g. 4-year Bachelor in Education (BEd) degrees and 1-year Postgraduate Certificate in Education (PGCE) programmes); (iii) the relationship between postgraduate degrees and the undergraduate disciplines from which they recruit (e.g. Theology \& Religious Studies); (iv) the content and nature of continuing professional development (e.g. provided by higher education institutions, RE Teacher Centres and other organizations); and (v) RE-specific training for specialist RE teachers (mostly secondary school teachers) and RE-specific training for generalist teachers or teachers of other subjects (mostly primary school teachers). As in the German context, it is possible to identify several pathways of professionalization for teachers of RE, and to explore relational tensions between: provision for different school phases/types (e.g. admission requirements and academic levels); distinct training components (e.g. theory/praxis and academic/professional); personal and structural factors in different institutions/organizations (e.g. resources, staffing, and the positioning and accomplishments of personnel); educational and religious orientations (e.g. schools and faith communities); initial and continuing professional development; and the intersection of personal/social characteristics and types of provision, access to training, and professional roles. All have been influenced by changes in general education policy and teacher education legislation. These include policy developments that supported, and then subsequently reversed, the academization of teacher education, and those that progressively promoted subject-related specialization, even if subject-specific content knowledge was to be accrued through general academic study in advance of a time-pressured apprenticeship model of professional learning. Some significant developments in the history of the professional development of teachers per se (not teachers of RE specifically) have been mentioned in general histories of RE in England (e.g. expansion/contraction of teacher training provision, development of BEd degrees and PGCEs, and closure/amalgamation of church colleges) (Copley 2008), but there has been no large-scale, in-depth and systematic study of initial and continuing professional development of teachers of RE.

An overlapping area of focus historiographically has been the role of the Church in teacher training and continuing professional development. In the mid-nineteenth century, the Church of England ran the majority of training colleges (i.e. elementary school teacher training), and religion would have been a foundational dimension of general teacher professionalism. This dominance was gradually eroded as other (secular) stakeholders increased their involvement - not least the Day Training Colleges and then universities which, at least initially, concentrated on preparing those to enter secondary school teaching. The place of religion and religious education in teacher training would become less and less relevant for general teacher training and more important in terms of subject-related professionalization. Thereby it followed the same pattern of functional differentiation as identified in Germany. From 1970 until 1980, under the pressures of funding cuts and the reorganization of higher education, the number of Anglican teacher training colleges in England decreased from twenty-five to twelve, and seven of the remaining colleges later merged with other institutions. The closures and amalgamations can be seen as a weakening of the Church's influence in 
education and may have had a deleterious effect, not only on the extent to which it could influence the training of teachers of RE, but also on the proportion of trainees in toto who received RE-specific professional development. Nevertheless, the realization of historic endowments and assets associated with the buildings and estates of Church Colleges enabled the creation of trusts dedicated to the furtherance of theological and religious education in both Church schools and the wider maintained sector, funding the initial and continuing professional development of large numbers of teachers of RE, as well as projects, publications, conferences and commissions (Parker and Freathy 2020). Alongside the work of diocesan education officers, the church college trusts are a mechanism by which Anglican influence over the initial and continuing professional development of teachers has continued, even whilst other providers and types of provision, such as LEAs and RE Centres, have come and gone. This is one dimension of the much broader and complex history of the initial and continuing professional development of teachers of RE.

It has not been possible to fill the known lacuna in this wider historical field. To replicate the work of the German research team would require familiarisation with the history of a diverse range of exemplar and/or representative case study teacher education providers, specifically with regard to their involvement in the initial and continuing professional development of teachers of RE. The primary challenge in this regard is resourcing the opportunity to access and analyse the relevant archival materials. We have, however, been able to identify institutions and organizations that could be selected for investigation on the basis of the following criteria: types of training provider (i.e. universities, denominational and non-denominational teacher training colleges, and RE Centres); subject-related importance; geographical distribution (north, south and midlands of England); and the availability of extant (archival) sources. For the Institute of Education, London, for example, it is possible to access handbooks (1948-65), calendars (1965-81), regulations and syllabuses (1930-2005), annual reports (1933-86), Teacher's Certificate examination papers (1930-82), RE Diploma examination papers (1958-83), and records of the Divinity/RE Committee of the Academic Board (1949-77). The University of Birmingham Special Collections houses records pertaining to Westhill College, including Board of Studies minutes (1973-89), syllabuses and regulations (1960s-70s), RE Centre documentation (1974-92), RE Consultative Committee records (1980-89), and prospectuses and handbooks (c.1970-2000). In the same archives are located the Institute of Education, University of Birmingham Records, including handbooks (1952-68), syllabuses and prospectuses (1966-), and Board/School of Education minutes and calendars. By way of contrast, in the York St John Archive, one can find the archives of the York and Ripon Diocesan Training Colleges (1862-1975), and Ripon and York St John College (1975-); and in the Archives of Brunel University, it is possible to access sources pertaining to Borough Road College RE Department and the Regional RE Centre based there. For Borough Road College these sources include course administration documentation (1960s-70s), teaching materials, staff information (1960s-70s), student recruitment data (1962-72), student registers (1964-67 and 1971-72), notes on external speakers (1969-73), films used as teaching aids (1969-72), prospectuses (1966-76), students' reflections on Divinity teaching (1962), and Teaching Practice lesson outlines (c.1960s). For the RE Centre, there are administrative documents (1973-75), notes on religious services (1960s-70s), and various teaching materials and book lists from the 1970s. The abundance of sources available for these institutions alone demonstrates the framework described in the preceding chapter could be applied as part of an empirically-based research project in the English context.

\section{Professional knowledge}

In terms of the body of specialized knowledge associated with the professionalization of teachers of RE in England between 1944 and 1988, it is possible to analyse subject-related discourses and leading publications in RE systematically and diachronically, and thereby capture continuities and changes in the content and structure of such professional knowledge, as well as the personal and professional backgrounds of the authors, and the intended readership. Subject-related academic discourse can be explored through the principal journal for RE in this period, Religion in Education (1934-1961), which changed its name to Learning for Living (1961-1978), and then to the British Journal of Religious Education from 1978 onwards. Only partial analyses of this journal(s) have been undertaken to date, and then only with regard to particular timeframes or content (Copley 1996, 1998; English et al 2003, 2005). Other less prominent journals that could also be investigated include the Bulletin of the Association of Lecturers and Teachers in Further and Higher Education (1965-1976), Journal of Beliefs and Values (1977 onwards), and Spectrum (1968-1996). It is also possible to identify foundational theoretical contributions and textbooks used on teacher-training programmes (e.g. Cox 1966; Holm 1975; Grimmitt 1978; Hull 1982). Since the number and variety of such publications was growing steadily during the period under scrutiny, similar criteria for selection as those 
deployed by the German research team could be deployed (e.g. scope of content, distribution, citation and reputation).

By way of exemplification, in previous publications (e.g. Freathy et al 2014; Parker et al 2016) we applied the constituent elements of professional knowledge (as described in the preceding chapter) in analyses of Religion in Education (RiE). This journal was launched in 1934 by the Student Christian Movement, as a forum for promoting dialogue about religion in education, both promoting and reflecting the growing professionalism among religious educators through campaigns for better staffing, curriculum resources and teacher training. It became affiliated to the ecumenical Institute of Christian Education at Home and Abroad (ICE) (est. 1935) (Parker et al 2016), which provided an organizational structure for cohering and developing the profession, and RiE provided the means for defining and disseminating professional knowledge. The multi-denominational editorial board of $R i E$ was derived from schools, teacher-training colleges, universities, churches, the Student Christian Movement, the ICE, and Government. Its first editor, from 1934-1957, was Basil Yeaxlee whose early editorials demonstrate his concern for all elements of professional knowledge, albeit to greater or lesser extents (see Freathy 2005: 108-110): 'Biblical Studies, aims and methods in teaching, worship, the relationship of Scripture to other elements in the curriculum, the psychology of religion and of religious growth in childhood and adolescence, questions of educational policy, enterprise and experiment in religious education overseas, news, and information about books' (Yeaxlee 1937a: 1). Yeaxlee's primary interest was to ensure that education was religious, and that religious education was professional (Yeaxlee 1934a: 61). He expressed deep commitment to the advancement of subject-specific content knowledge (e.g. Yeaxlee 1935), and advocated many forms of, and reforms within, initial and continuing professional development (e.g. Yeaxlee 1934b; 1936). He had a more wide-ranging conception of professional knowledge than many contributors to RiE, who often ignored knowledge of subject-specific pedagogical methods and generic pedagogical and psychological knowledge, and who perhaps over-relied on pragmatism combined with ideological ends. However, in an international context characterised by profound social, cultural and political change, mostly precipitated by the approach, and then commencement, of the Second World War, it is understandable that so much attention was given to constructing and articulating the aims and purposes for religious education (Freathy 2008a), the wider curriculum and schooling in general, and concomitantly, the professional identity, role and responsibilities of $\mathrm{RE}$ and other teachers.

In our case study of RiE between 1942 and 1947 (vols. 9-14) discussion about, then ratification of, the 1944 Education Act and its outworking dominated (Freathy et al 2014), reflecting an appreciation of the urgent need to train expert teachers in the light of the institution of statutory RE provision and the raising of the school leaving age (e.g. Harrison 1945; Barker 1946). In terms of professional knowledge, RiE articles emphasised subject-specific content knowledge, especially biblical studies, and to a lesser extent theology and church history, reflecting prevailing trends in Agreed Syllabuses and a growing consensus concerning what should be taught (e.g. Hargreaves 1943; Mason 1943; Bodell 1944). Contributing authors included many leading biblical scholars (e.g. T. H. Robinson, C. H. Dodd and H. H. Rowley). There were very few articles about subject-specific pedagogical methods, and little consideration of technical and procedural matters, other than occasional 'how to' guides (e.g. Yeaxlee 1945; Grayston 1945). With regard to generic pedagogical and psychological knowledge, only four articles in RiE during the period drew upon psychology and focused upon knowledge of child development (Backhouse 1945; Martin 1946; Hall 1946; Morrison 1947). Non-subject specific teaching, learning and assessment processes, or conceptions of children as religious subjects in their own right, were not deemed important constituents of professional knowledge for religious educators. Lacking empirical basis, the majority of articles were scriptural expositions or personal reflections upon current circumstances, based on the disciplinary foundations (if any) of Biblical Studies and/or Theology.

In terms of orientative knowledge, many contributors emphasized the successes of the ecumenical movement, and the wartime context coalesced and catalysed the ongoing development of a coherent, nondenominational, philosophy of (religious) education (Parker et al 2016) which was seen to be key for Christianising education and society (Freathy 2007, 2008; Parker 2012). A central theme to emerge when discussing the professional identity, role and responsibility of teachers of non-denominational RE was their autonomy from ecclesiastical authority and clerical control, and how the provisions of the 1944 Education Act would influence the relationship between teachers/schools and clergy/churches, not least in terms of the religious testing of teachers (impacting appointments/promotion), and determination of curriculum content 
and methods (e.g. Harrison 1945; Yeaxlee 1942). Discourse placed RE teaching as a vocation (Rawlinson 1947); and the teacher in the position of spiritual inspiration (Yeaxlee 1944: 2) and 'pastor' (Tatlow 1945: 33). Sincerity was deemed a vital characteristic (Jessop 1945), as was objectivity in the presentation of material, even if it was naturally assumed the teacher was Christian (Backhouse 1945).

Our analysis of RiE confirms the validity of the constituent elements of professional knowledge identified in the preceding chapter, albeit noting a concern for ideological ends rather than pedagogical means (Freathy et al 2016). Our analysis also demonstrates inter-connections between academic discourses, organizational politics and the nature of professional development, thereby evidencing conceptual overlaps between professional self-organization and politics, professional development and professional knowledge. By the 1940s, there was an identifiable interdenominational movement for Christian education, drawn from university and training college lecturers, secondary school teachers, educational administrators, lay and clerical church members, writers and politicians. They promoted a liberal, ecumenical and Protestant 'philosophy of religious education' (Bates 1976; Michell 1985) which held sway until the mid-1960s (Hull 1975: 23). Using the three concepts of 'education', 'religion' and 'life' often interchangeably (see Bates 1976; Doney 2015), it promoted the natural growth, nurture and cultivation of the whole person, and sought to break down the divisions between different forms of curriculum, and between school and life (Michell 1985). Religion was a subject of teaching and a way of living: it was to be taught through RI, and caught through religious education in a broader devotional, practical and pastoral sense (Bates 1976; Copley 2002; Freathy 2005). The ICE's network of committees, conferences and publications provided the chief medium for disseminating this philosophy, and helped to confer upon teachers a collective sense of professional identity, role and responsibilities (Parker et al 2016). Nevertheless, such a broad conceptualisation of religious education did not support the idea that teachers of RI/RE are set apart from other teachers by specialised knowledge or exclusive practical expertise (Parker et al 2016). Where professionalization was promoted, it was often with regard to all teachers vis-a-vis Christian education generally, and not just teachers of RI/RE specifically, thereby meaning their particular professionality and individual professionalization remained under-conceptualised.

Although we have not applied the same analytical framework to the full run of RiE and its successors, some broad reflections can be made. In the early 1960s, it was decided to rename RiE as Learning for Living: a journal of Christian Education. This decision was partly financial, but also partly theoretical, in terms of the quantity and type of professional knowledge that RI/RE teachers were expected to acquire (Parker et al 2016). Successive editors of Learning for Living were: Harold Loukes until 1964; David Ayerst, 1965-67; and Catherine Fletcher, 1967-71. It was under the editorship of John Hull (1971-78), in the midst of (multi)cultural wars about the nature and purpose of RI/RE, that the journal was re-launched again as the British Journal of Religious Education in 1978, promoting an open, enquiring, multi-faith approach towards (religious) education, underpinned by the ethos of the Christian Education Movement (the successor of the ICE) (Hull 1978). Changes in journal title, function and format highlight transitions in the shape of English religious education (Parker et al 2016). RiE discussed religious education in a broad sense, in terms of biblical and theological scholarship from a Christian perspective, primarily disseminating orientative knowledge and subject-specific content knowledge. Learning for Living was predominantly concerned with RI, and subject-specific content knowledge and subject-specific pedagogical methods in particular, still within a national and ecumenically-Christian frame of reference. By the 1970s, awareness of growing religious and secular plurality at home, and of religious education research, policies and practices abroad (Parker and Freathy 2011a; Freathy and Parker 2013), helped to diversify and internationalise the contents of, and contributors to, the British Journal of Religious Education.

In conclusion, from the evidence we have considered thus far, there is no singular and stable conception of the professional knowledge prescribed for English teachers of RI/RE either synchronically or diachronically. Despite some coalescence in subject-related discourses around a broad Christian philosophy of education, at least in the early part of the 1944-1988 period, this excluded certain perspectives (most notably Catholics) and masked underlying tensions and nuances. The development of RiE and its successors evidences to some extent the specialization, academization and scientification of the academic discipline of religious education, although by the end of our period, this might be better described as a multi-disciplinary field of enquiry, utilising increasingly research-based knowledge derived from evermore social scientific and empirical studies, alongside theological and theoretical essays. It is unclear, however, the extent to which this is indicative of the professionalization of teachers of RE or simply those engaged in related academic 
discourses. Further research is necessary to understand what knowledge teachers of RE were encountering and how (e.g. through initial and continuing professional development). As with the German case study, it is anticipated that the components of professional knowledge of English teachers of RE could be conceived over time in terms increasingly common to those of other teachers, with lessening emphasis being placed on personal characteristics (including faith) of teachers, and growing emphasis on subject-specific and generic pedagogical methods.

\section{Professional self-organization and politics}

Teachers of RE in England have not had considerable amounts of professional autonomy nor have they effectively self-organized (in terms of qualifications, good practice, a professional ethos, etc.). Instruments of the state, faith groups and other stakeholders have steered relevant processes in professional politics, and various institutions, organizations, groups and networks have played key roles in shaping or representing professional interests. Following on from our previous discussion of the impact of government legislation on the professionalization of teachers of RE in England, we here continue our exploration of professional politics with reference to the influence exercised by national bodies, such as His/Her Majesty's Inspectors (1840-), the Consultative Committee of the Board of Education (1899-1944), the Central Advisory Council for Education (England) (1945-1967) and the School's Council (1964-1984). By way of illustration, we turn to the publications of the Consultative Committee of central government's Board of Education (1899-1944) in the period between the First and Second World Wars when, arguably, state-sponsored professionalization of teachers of non-denominational RE in England began in earnest. Until then, and even during that period, official publications tended to leave religious education alone to avoid arousing controversy (ICE 1954: ix). Of the little that such reports did say (Board of Education 1926; 1928; 1931), and in accordance with the recommendations of the Commission on Religious Education appointed by the Archbishops of Canterbury and York in 1929, there was general acceptance that religious training was more than the acquisition of knowledge, and should also be undertaken through worship in school prayers and through the school life and discipline (Board of Education 1933: 131). Conferences convened in November 1933 and March 1934 by Lord Halifax (President of the Board of Education), promoted the provision of improved opportunities for teachers to equip themselves for giving RI, particularly by university teacher training departments and teacher training colleges (Board of Education 1934). The conferences were predicated on an increased interest in, and quality of, RI in both elementary and secondary schools, and in opposition to the neglect of Scripture teaching in secondary schools, particularly because of the negative implications this had for those wishing to become teachers (Yeaxlee 1934: 122).

The Consultative Committee report that most impacted the post-Second World War professionalization of teachers of RE was the Spens Report on secondary education (1938). It sought to counter both the tendency of schools to exclude RI from the timetable of year groups undertaking public examinations, and the large number of teachers who were unwilling to teach Scripture. It stated that, "no [student] can be counted as properly educated unless [(s)he has] been made aware of the fact of the existence of a religious interpretation of life', and advocated an expert historical and objective approach based on knowledge of ancient history, biblical criticism and theology (pp. 208-9). Whilst recognising arguments in favour of Scripture being taught by Form teachers, or indeed Head teachers, the overall message was clear: if 'Scripture is to be taught as a subject valuable for its own interest and intellectual discipline it requires, to the same extent as any other subject of primary importance, the direction of a specialist teacher' (p. 211). It did not advocate that a specialist should provide all Scripture teaching, or that the qualifications and teaching of any Scripture specialist should be confined to that subject. Indeed it accepted that the number of teachers who have undertaken university courses and passed examinations in biblical and kindred subjects would 'be far from sufficient to meet the demand' (p. 213). Instead, it suggested existing teachers of other subjects should qualify themselves by study leave, part-time degrees and diplomas, extra-mural university courses and vacation courses. The report also distinguished, and promoted links, between Scripture and religious education of a more general kind (including worship and prayers), which would 'deal more directly with the application of Christian principles' to the personal and public problems of adult life and/or 'attach some significance' to the Christian interpretation of life, and the will to act on its assumed truth (p. 216).

In terms of professional self-organization, we can refer to primary research already undertaken on the origin, role and function of the interdenominational Institute of Christian Education at Home and Abroad (ICE) (est. 1935 ) and its successors, which became the pre-eminent organization for RE in England in the period and was foremost in offering professional development for teachers of RE for decades (Parker et al 2016). The 
University of Birmingham Special Collections houses the archives of the ICE 1935-65), the Student Christian Movement in Schools (SCMS) (1943-65), and the Christian Education Movement (CEM) (19652001), including minutes of meetings, administrative files, correspondence (with other RE organizations), pamphlets, leaflets and publications, and study packs for teachers. The ICE was largely borne out of the evangelical missionary zeal leading to the foundation of the Student Christian Movement (SCM) in 1898 and its Auxiliary Movement in 1912 (Freathy 2005: 56), and the growing international ecumenical movement, particularly the World Missionary Conference (Edinburgh, 1910) (Hastings 1997: 87; cf Doney 2015). The leaders of the Auxiliary Movement's Schools Department (est. 1922), including Basil Yeaxlee, as well as other personalities associated with the SCM and Edinburgh conference, were influential in the burgeoning Christian education movement, and development of an ecumenically-minded view of religious education in non-denominational state-maintained schools (Bates 1976: 316; see Parker et al 2016). If denominational disputes surrounding the development of publicly-maintained schools formed the troubled backdrop from which RE in such schools emerged, then interdenominationalism paved the way for its professionalization (Parker et al 2016).

In April 1931, the Auxiliary Movement and the Advisory Council for Christian Education Overseas (a subcommittee of the International Missionary Council, est. 1921 [see Bates 1976: 101-3]) jointly ran a conference for teachers on 'Christian Education at Home and Overseas'. Following J. H. Oldham's lead, the Conference resolved to establish an organization of those concerned with RI to undertake a continuous, systematic and coordinated study of Christian education with a view to raising its standard and efficiency. The committees and groups formed to take forward this vision were characterised by multi-stakeholder constituencies including university and college teacher trainers, headteachers, teachers, missionaries, theologians, and clerical and lay representatives of the churches. In the meantime, as a provisional measure, an Association for Teachers of Religious Knowledge (ATRK) was founded on a professional and technical basis akin to other professional teacher associations, albeit widened to include teachers from overseas. From its inauguration in January 1932, under the Presidency of Henry Hadow, it sought to represent the needs of the subject to LEAs and other interested bodies, and to enlist the help of scholars in forming a link between research in the universities and teaching in schools. The improvement of religious teaching in schools, according to a resolution passed at the ATRK's first conference (January 1934), was 'dependent to a large extent on the growth of a body of men and women specially qualified in the subject, so that in the majority of schools there could be a member of staff capable of advising on the planning of the syllabus, the choice of books for reference or study, etc., and who could take a considerable but not exclusive part in the teaching of the subject' (Matthews 1934: 103). Subsequent to a second 'Christian Education at Home and Overseas' conference (April 1934), the Institute of Christian Education at Home and Abroad (ICE) was established, subsuming pre-existing committees and groups, including the ATRK. The Anglican Archbishop of York, William Temple, became the ICE's first President; Tissington Tatlow became its first director; and Henry Hadow and John Scott-Lidgett became Vice-Presidents. For Temple, the professionalization of religious education would counter the secularisation of society by ensuring that the whole of school life provides training in Christian citizenship (Temple 1936: 181; see also Parker 2005: 202; Freathy 2008b: 109). By 1939 , the ICE had nearly 2,000 members and over 3,000 by 1945. It produced books, pamphlets and tracts, as well as providing a forum for debate, thereby offering opportunities to build a professional knowledgebase, and the means to disseminate it, including advertising initial and continuing professional development provision. Professionalization, not exclusive specialization, was the aim: the distinctive roles of Specialist, Semi-specialist and Non-specialist teachers of RE continued to be recognised and defended (ICE 1954).

Beyond involvement in subject associations, the control and organization of RE teachers and teaching exercised by faith groups has been brought to bear by other means, not least the role of church leaders in influencing the development of RE's distinctive legislative framework in the exceptional religio-cultural and socio-political context of the Second World War. Wartime conditions stoked a grave and growing concern for the people's morality and spirituality which fuelled public and political discourse about the present and future state of religious education in schools. In February 1941, the Anglican archbishops of Canterbury, York and Wales issued a joint statement on 'True Christian education' (Anon. 1941a) which - after welcoming the recommendations of the Spens Report for secondary education - presented five recommendations for elementary education including: (i) trainee teachers should be given an enhanced full option subject course in Religious Knowledge which could count in the Board's Teaching Certificate; (ii) the law restricting the teaching of RI to the beginning or end of the school day should be abolished, so that specialist RI could be given at any time; and (iii) religious teaching should be subject to inspection as were 
other subjects (Parker and Freathy 2020). This was justified on the basis of 'an ever-deepening conviction that if there is to be any civilization worth having it must be based upon [the Christian] faith' (Anon. 1941b). Subsequently, the 1944 Education Act removed the 'Timetable clause' and stipulated that RI in LEA schools should be inspected by His Majesty's Inspectors (or equivalent), and 'non-Agreed Syllabus' RI in 'voluntary' schools should be inspected under arrangements made by the school managers/governors.

By the mid-1960s, there was some disillusionment with the endeavours of the ICE, and the ability of the religious provisions within the 1944 Education Act to further the campaign for Christian education (ICE 1954). From September 1962, developments had been taking place towards the establishment of a separate Association for Christian Education, which would draw its membership from the ICE and the SCM in Schools. The merger came to pass in 1965 through the creation of the interdenominational and theologicallyliberal Christian Education Movement (CEM). It became the leading organization for English religious educators, working alongside the churches and LEAs to support the professional development of teachers of RE, through its regional advisors, publications and courses, including residential conferences (Copley 2008: 87). It also cultivated dialogue and good relations with other faiths, and later published multi-faith curriculum resources for schools (Copley 2008: 87). Nevertheless, as the aims and purposes of religious education in schools became increasingly challenged by secularists and humanists (Freathy and Parker 2013; Doney 2015), as well as from educational researchers and teachers, the fragile unity that the CEM and its predecessors had worked hard to maintain came under increasing pressure (Parker and Freathy 2011a; Freathy and Parker 2013). This is apparent not least from the emergence of rival organizations, such as the short-lived National Association for Teachers of Religious Knowledge (NATORK) in 1967, representing a more conservative, dogmatic and evangelically Christian view of the nature and proselytising purpose of religious education (Freathy et al 2014: 226; Parker et al 2016); and the Association of Religious Education (ARE) in 1968, which was established by Peter Lefroy-Owen, with its own regular bulletin (AREA), 'to express the religious independence and professionalism of teachers in the subject' (Copley 2008: 106). By the late 1960s and early 1970s, the 'non-confessional' trends of development in the subject, leading to increasingly multi-religious and secular curriculum content (Freathy and Parker 2013, 2015), divorced from direct religious purpose and intent, were seemingly irreversible in the face of growing cultural diversity and increasing challenges to the legitimacy and relevance of religious education in non-denominational, statemaintained schools. Indeed, despite its theological liberalism and ecumenical reach, the rise of open-ended, multi-faith and phenomenological RE, as well as the increasing numbers of LEA advisory posts in RE, 'coincided with the decline of the [CEM]' and supplanted the role of its Regional Advisors respectively (Copley 2008: 106). Other organizations continued to emerge, such as the National Association of Teachers in Further and Higher Education Religious Studies Section which was established in 1976 with a journal entitled NATFHE Religious Studies Section Bulletin (Campbell 1997). An attempt to create a single professional organization for RE nationally, incorporating the CEM Teachers' Committee and ARE, led to the creation of the Professional Council for RE (PCfRE) in 1985 (Copley 2008: 106).

In parallel to these developments, the specific expert committees and boards, founded within the Protestant churches over time to substantiate their educational positions and interests, continued to meet and have influence, including the Church of England's Board of Education and National Society for Promoting Religious Education, the Free Church Federal Council Education Committee, and the British Council of Churches' Education Department. These bodies and their publications had strong steering effects on RE policy in England, exerting an influence over the nature and purpose of the subject in all schools. The Church of England Record Centre houses the archives of the National Society for Promoting RE, including annual reports, RE Centre minute books and agenda (1971-77), and working papers of various commissions, consultations, enquiries, initiatives and reports (1945-86). It also houses the British Council of Churches Archive (1942-92) which includes, for example, papers and correspondence concerning the nature and future of RE (1963-66) and the background papers to various RE commissions and studies (1961-74). One notable example can be highlighted to demonstrate the potential benefits of analysing the publications and archival sources originating from these groups. That example is a report of the working party, established by the Education Department of the British Council of Churches with support of the Department of Education Science, on the recruitment, employment and training of teachers concerned with religious education in schools in England and Wales (British Council of Churches 1971). It noted that more than half of those teaching religious education in maintained schools lacked a relevant specialist qualification and this proportion was overwhelmingly greater in primary schools. Bearing in mind the importance of secondary education for conferring knowledge about religion(s) to future non-specialist teachers of RE, the small and 
diminishing amount of time allocated to religious education in secondary schools was lamented. The report was also critical of the working conditions of religious education specialists, and the inadequate provision of both initial and continuing teacher training by specialists. The recommendations promoted diversification of modes of recruitment and training; increased time allocation, resourcing and status to RE teaching and teachers (including the provision of advisors, teachers centres, material aids, and in-service courses); and revision of the training curricula suitable for teachers in different phases, with differing levels of expected expertise, and in the light of ongoing reforms of the school RE curriculum (Anon. 1971: 4). Another priority identified was the need for collaboration between stakeholders.

In 1972, the CEM Teachers' Committee, in collaboration with ARE, sponsored the founding of a Religious Education Council for England and Wales (REC) in an attempt to represent a wider cross-section of teachers of RE than CEM, and to create a single, authoritative federal body. Established in 1973, the REC drew together member bodies representing not only teachers of RE and their professional/subject associations, but also the main Christian denominations, other faith communities and humanists, and academic and professional associations involved in the study of religions (Parker et al 2016). Further research would be needed to recount the parallel histories of these different groups and map the relations between them, as well as to assess whether their existence signifies the vigour of the subject or a structural weakness. While teachers of RE have corporate responsibility towards those who share their educational and societal concerns, it is questionable whether further professionalization can occur without them attaining more autonomy in the area they profess: defining, governing and supporting RE; organizing and representing themselves; and determining their own professional knowledge, standards and expertise, as well as the means by which they are acquired and assured (Parker et al 2016). Bodies such as the ICE and its successors, and the REC, might be better described as organizations for teachers of RE rather than organizations of teachers of RE, and possibly even better described as subject associations rather than professional associations. Like Agreed Syllabus Conferences and SACRE, they provided a means of achieving and/or expressing ecumenical co-operation in education, following decades of denominational dispute, but teachers of RE were often placed in a minority position in which their autonomy and aspirations for selfdetermination were constrained. While the REC campaigned from its inception for adequate specialist RE teacher recruitment, employment and training (REC 1978; 1979; 1982; 1984; 1986), its existence depended to an extent - like that of other RE subject associations - on the frailty of the profession and the profession's reliance on external stakeholder support. Such outside bodies organized teachers of RE, created and disseminated professional knowledge, and offered professional developmental opportunities. Thus they simultaneously promoted and prohibited the professionalization of teachers of RE in England: a history of organizing a profession not of professional self-organization. To understand this more holistically, a systematic chronological study could be undertaken of the publications and archives of such organizations with regard to: their missions, aims, facilities, functions, characteristics, membership and affiliations; the conceptions of professionalism that were held within them; and their role (if any) in helping or hindering the processes by which teachers of RE were professionalized.

\section{Conclusion}

In certain respects, it is possible to see increasing professionalization of teachers of RE in England since the early twentieth century, particularly in the secondary school phase. Teachers of RE have benefitted perhaps most significantly from 'non-subject-specific' steps towards the professionalization of the teaching profession more generally, although RE may be an outlier in some primary schools due to an ongoing and unwelcome dependency on unqualified teachers. Examples of generic policies affecting teacher professionalization more broadly include those pertaining to teacher training institutions and their organization and funding; the length of training courses and the qualifications conferred; and teacher remuneration (see, for example, Board of Education 1944; Committee on Higher Education 1963; Department of Education and Science 1972; Committee of Inquiry into the Pay of Non-University Teachers 1974). Even though their membership included teachers of RE, our analysis excluded teachers' unions, such as the National Union of Teachers, and organisations like the Association of Christian Teachers (ACT), because they were not subject-specific in orientation. Nevertheless, the activities of teachers' unions will have influenced the professionalization of teachers of RE at least indirectly, and the emergence and continuation of the ACT (est. 1971) will have intersected with developments within, and relating to, the history of RE and religious education more broadly. As the fortunes of RE as a curriculum subject have waxed and waned, so have the processes of professionalization and de-professionalization of the subject's teachers, with higher and lower degrees of professionalization being evident at different times, often due to 
political decisions beyond the control of those immediately concerned with the subject. A continuity across the twentieth century and beyond is a concern for the long-term future of RE and regular crises of confidence regarding its status, position, resourcing, and so forth, particularly in schools without a religious affiliation. It is not possible to assert, at least with any confidence, that historical developments in teacher training, the delineation of professional knowledge and the effects of professional politics have led to progressive professionalization and the structural and institutional presuppositions that would make it possible to achieve fully professional teachers of RE. Here it would be beneficial to compare and contrast the historical and current circumstances in England within those of other countries in the Western world, specifically with regard to the contextual factors that have helped and hindered the professionalization of teachers of RE, and what may be learned from such comparisons to improve the situation in England. In this regard, we note a particular lacuna in the historiography of English RE (see Freathy and Parker 2010) pertaining to the initial and continuing professional development that teachers of the subject have received over time. The preoccupation with the lack of subject specialists may be compared with the paucity of attention paid to the nature of the desired specialism and the structures and processes that promote its acquisition. On this and other topics, future research could explore the professionalization of teachers of RE in the context of international developments and transnational movements, including, for example, the impact of policy borrowing and legislative emulation due to imperial influences across the Anglo-sphere (Jackson 2020).

In this chapter, using evidence drawn from previous research, we hope to have demonstrated that it is possible to apply the operational definition of professionalization used by the German research team to the historical and institutional processes associated with the professionalization of teachers of RE in England at each of the above three conceptual levels. Theories of professionalization resonate with the historical developments in England just as they do in Germany. A more detailed and comprehensive application of this methodology over the entire period with regard to the analysis of $R i E$ (and its successors) and the ICE (and its successors), as well as with regard to other academic/professional journals and subject/professional organizations, would provide a more longitudinal and holistic perspective. Similarly, a richer and more nuanced history would be attained through the systematic use of the full-range of primary sources indicated (e.g. core textbooks; the archives of relevant institutions and organizations; and (un)published documentary evidence pertaining to political and legislative developments). Through the arguments and evidence presented in this chapter, and with these future possibilities in mind, we hope at least to have demonstrated the potential of the approach. At the same time, we recognise that a thoroughgoing history of the professionalization of teachers of RE in England cannot be reconstructed properly without reference to wider social, cultural, religious and political events, as well as broader developments in the history of teachers, schools and (religious) education generally. Space does not permit a full exploration of such contextual influences here, but we have discussed some in earlier studies (see Parker and Freathy 2011a, 2011b; Freathy and Parker 2012, 2013; Freathy et al 2015). We have not yet attempted to provide a history of wider Christian involvement in education, such as that represented amongst denominational societies across this period (Raftery 2012). A systematic, denominationally-differentiated history of the religious curriculum of schools in the English context has yet to be written (Parker et al 2016). To this end, a thoroughgoing religious historical literacy would be essential, as it is to understanding the development of educational policies, practices and/or institutions in any temporal and spatial context (Parker et al 2020).

\section{References}

All Party Parliamentary Group. 2013. RE: The Truth Unmasked. The supply of and support for Religious Education teachers. An Inquiry by the All Party Parliamentary Group on Religious Education. Available online at: http://www.recouncil.org.uk/images/stories/pdf/APPG RE The Truth Unmasked.pdf. [Accessed 22 June 2015]

Anon. 1941a. 'True Christian Education.' The Times, 13 February 1941. Page 2.

Anon. 1941b. 'True Christian Education: Primate on Present Urgency.' The Times, 25 February 1941. Page 2.

Anon. 1971. 'Editorial.' Learning for Living 10(5): 4.

Backhouse, W. H. 1945. 'Religious developments in adolescence.' Religion in Education 12(3): 74-77.

Barker, G. D. 1946. 'The Butler Act in Practice.' Religion in Education 13(2): 38-40.

Bates, D. J. 1976. The Nature and Place of Religion in English State Education c1900-c1944 with Special Reference to Conceptions of the relations of Religion to Education and the development of Christian

Education c1920-c1944. Unpublished Ph.D. Thesis, University of Lancaster. 
Board of Education. 1926. The Education of the Adolescent [The Hadow Report]. London: H. M. Stationery Office.

Board of Education. 1928. Books in Public Elementary Schools. London: H. M. Stationery Office.

Board of Education. 1931. The Primary School. London: H. M. Stationery Office.

Board of Education. 1933. Infant and Nursery Schools. London: H. M. Stationery Office.

Board of Education. 1934. The Provision of Improved Opportunities for Teachers to equip themselves for giving Religious Instruction. London: H. M. Stationery Office.

Board of Education. 1938. Secondary Education with Special Reference to Grammar Schools and Technical High Schools [The Spens Report]. London: H. M. Stationery Office.

Board of Education. 1944. Teachers and Youth Leaders : report of the Committee Appointed by the

President of the Board of Education to Consider the Supply, Recruitment and Training of Teachers and

Youth Leaders [McNair Report]. London: H. M. Stationery Office.

Bodell, D.L. 1944. 'Using an Agreed Syllabus in an Elementary School.' Religion in Education 12(1): 19-22.

British Council of Churches. 1971. The recruitment, employment and training of teachers concerned with religious education in schools in England and Wales. London: British Council of Churches.

Campbell, W.S. 1997. 'Editorial.' Journal of Beliefs and Values 18(1): 5-6.

Committee of Inquiry into the Pay of Non-University Teachers. 1974. Report of the Committee of Inquiry

into the Pay of Non-University Teachers [Houghton Report]. London: H. M. Stationery Office.

Committee on Higher Education. 1963. Higher Education: report of the committee appointed by the Prime

Minister under the chairmanship of Lord Robbins, 1961-63 [Robbins Report]. London: H. M. Stationery

Office.

Conroy, J., D. Lundie, R. A. Davis, V. Baumfield, L. P. Barnes, T. Gallagher, K. Lowden, N. Bourque and

K. Wenell, K. 2013. Does Religious Education work? A multidimensional investigation. London:

Bloomsbury Press.

Copley, T. 1996. "A Tribute to John Hull: A Review of Editorials in Learning for Living and the British

Journal of Religious Education, 1971-1996.” British Journal of Religious Education 19(1): 5-12.

Copley, T. 1998. 'Rediscovering the Past: Writings on Religious Education in Religion in Education

Quarterly, 1934-39, Raises Some Questions for Today's Religious Educators.' British Journal of Religious

Education 20(2): 82.

Copley, T. 2002. Black Tom Arnold of Rugby: The Man and The Myth. London: Continuum.

Copley, T. 2008. Teaching Religion. Exeter: Exeter University Press.

Cox, E. 1966. Changing aims in religious education. London: Routledge and Kegan Paul.

Department of Education and Science. 1972. Teacher education and training [James Report]. London: H. M.

Stationery Office.

Department of Education and Science. 1983. Teaching quality. London: H. M. Stationery Office.

Doney, J. 2015. "“That would be an ecumenical matter": Contextualizing the Adoption of the Study of World

Religions in English Religious Education Using "Statement Archaeology", a Systematic Operationalization

of Foucault's Historical Method. Unpublished PhD thesis, University of Exeter.

Doney, J. (Forthcoming). Unearthing Policies of Instrumentalization in English Religious Education: Using

Statement Archaeology. Abingdon: Taylor and Francis.

English, L. M., M. O. D'Souza, and L. Chartrand. 2003. 'A 10-year Retrospective of the British Journal of

Religious Education: An Analysis of Contents and Contributors.' British Journal of Religious Education

25(4): 308-319.

English, L. M., M. O. D'Souza, and L. Chartrand. 2005. 'Comparative Analysis Of The Research and

Publication Patterns In British Journal Of Religious Education And Religious Education.' Religious

Education 100(2): 193-210.

Freathy, R. J. K. 2005. Religious Education and Education for Citizenship in English Schools, 1934-1944.

Unpublished Ph.D. Thesis, University of Exeter.

Freathy, R. J. K. 2007. 'Ecclesiastical and religious factors which preserved Christian and traditional forms of education for citizenship in English schools, 1934-1944.' Oxford Review of Education 33(3): 367-377.

Freathy, R. 2008a. 'The Triumph of Religious Education for Citizenship in English Schools, 1935-1949.'

History of Education 37(2): 295-316.

Freathy, R. J. K. 2008b. 'Three Perspectives on Religious Education and Education for Citizenship in

English Schools, 1934-1944.' British Journal of Religious Education 30(2): 103-112.

Freathy, R. and S. G. Parker. 2010. 'The necessity of historical inquiry in educational research: The case of

Religious Education.' British Journal of Religious Education 32(3): 229-243. 
Freathy, R. and S. Parker. 2012. 'Freedom from Religious Beliefs: Humanists and Religious Education in England in the 1960s and 1970s', in: Religious Education and Freedom of Religion and Belief edited by S. Parker, R. Freathy and L. J. Francis, 7-27. Oxford: Peter Lang.

Freathy, R. and S. Parker. 2013. 'Secularists, Humanists and Religious Education: Religious crisis and curriculum change in England, 1963-1975.' History of Education 42(2): 222-256.

Freathy, R. and S. G. Parker. 2015. 'Prospects and Problems for Religious Education in England, 1967-1970: curriculum reform in political context.' Journal of Beliefs and Values 36(1): 5-30.

Freathy, R., S. Parker, F. Schweitzer and H. Simojoki. 2014. 'Towards international comparative research on the professionalization of Religious Education.' Journal of Beliefs and Values 35(2): 225-241.

Freathy, R., S. G. Parker, and J. Doney. 2015. 'Raiders of the Lost Archives: Searching for the Hidden History of Religious Education in England', in: History, Remembrance and Religious Education edited by S. G. Parker, R. Freathy and L. J. Francis, 105-137. Oxford: Peter Lang.

Freathy, R., S. Parker, F. Schweitzer and H. Simojoki. 2016. 'Conceptualizing and Researching the Professionalization of Religious Education Teachers: Historical and International Perspectives.' British Journal of Religious Education 38(2): 114-129.

Grayston, K. 1945. 'Broadcast Talks.' Religion in Education 13(1): 22.

Grimmitt, M. 1978. What can I do in R.E.?: A consideration of the place of religion in the twentieth-century curriculum. Great Wakering: Mayhew-McCrimmon.

Hall, P. 1946. 'The Modern Child's Religion-A question.' Religion in Education 13(3): 80-81.

Hargreaves, H. L. 1943. 'The Agreed Syllabus in Practice.' Religion in Education 11(1): 9-12.

Harrison, J. G. 1945. 'The Butler Act in Practice.' Religion in Education 12(2): 43-45.

Hastings, A. 1997. The Construction of Nationhood: Ethnicity, Religion and Nationalism. Cambridge: Cambridge University Press.

Holm, J. L. 1975. Teaching religion in school: A practical approach. London: Oxford University Press. Hull, J. 1975. School Worship: an obituary. London: SCM Press.

Hull, J. 1978. 'Editorial.' British Journal of Religious Education 1(1): 1-2.

Hull, J. 1982. New directions in religious education. Lewes: Falmer Press.

Institute of Christian Education. 1954. Religious Education in Schools: The Report of an Inquiry made by the Research Committee of the Institute of Christian Education into the working of the 1944 Education Act. London: National Society / SPCK.

Jackson, S. 2020. 'Religious Education and the Anglo-World: The Impact of Empire, Britishness, and Decolonisation in Australia, Canada, and New Zealand.' Brill Research Perspectives: Religion and Education 2(1): 1-98.

Jessop T. E. 1945. 'Standards in Religious Education.' Religion in Education 12(3): 66-69.

Martin, G. R. R. 1946. 'My son's religion.' Religion in Education 13(3): 77-80.

Mason, F. 1943. 'The School, the Church, and the Local Education Authority.' Religion in Education 11(1): 13-15.

Matthews, C. H. S. 1934. 'The ATRK Conference.' Religion in Education 1(2): 101-107.

Michell, C. 1985. Christian Education and the Christian Nation: a study of the role envisaged for religious education in British State Schools c.1920-1965. Unpublished M. Litt. Thesis, University of Cambridge. Morrison, N. 1947. 'The modern child's religion: A reply to Miss Phyllis Hall.' Religion in Education 14(2): 55-57.

OFSTED. 2013. Religious Education: Raising the potential. London: OFSTED.

Parker, S. G. 2005. Faith on the Home Front: aspects of church life and popular religion in Birmingham, 1939-1945. Oxford: Peter Lang.

Parker, S. 2012. 'Reinvigorating Christian Britain: the spiritual opportunities of the war, national identity, and the hope for religious education.' In God and War: the Church of England and Armed Conflict in the Twentieth-century, edited by S. G. Parker and T. Lawson, 61-79. Aldershot: Ashgate.

Parker, S. G. 2015. 'Mediatising childhood religion: the BBC, John G. Williams and collective worship for schools in England, 1940-1975.' Paedagogica Historica 51(5): 614-630.

Parker, S. G. and R. J. K. Freathy. 2011a. 'Ethnic diversity, Christian hegemony and the emergence of multifaith Religious Education in the 1970s.' History of Education 41(3): 381-404.

Parker, S. G. and R. J. K. Freathy. 2011b. 'Context, complexity and contestation: Birmingham's Agreed Syllabuses for Religious Education since the 1970s.' Journal of Beliefs and Values 32(2): 247-262. Parker, S. G. and R. Freathy. 2020. 'The Church of England and religious education during the twentieth century'. In The Church of England and British Politics since 1900, edited by T. Rodger, P. Williamson, and M. Grimley, 199-221. Woodbridge: Boydell \& Brewer. 
Parker, S., S. Allen, and R. Freathy. 2020. The Church of England and the 1870 Elementary Education Act. British Journal of Educational Studies, 1-25.

Parker S. G., R. Freathy, and J. Doney. 2016. 'The Professionalisation of Non-Denominational Religious

Education in England: politics, organisation and knowledge.' Journal of Beliefs and Values 37(2): 201-238.

Raftery, D. 2012. 'Religions and the history of education: a historiography.' History of Education 41(1): 4156.

Rawlinson A. E. J. 1947. 'The vocation of the Christian teacher.' Religion in Education 15(1): 3-6. Religious Education Council of England and Wales. 1978. The Development of RE: A Report on the recruitment and training of RE teachers. Farnham, Surrey: REC.

Religious Education Council of England and Wales. 1979. RE and the training of primary teachers: Report of a survey. Lancaster: REC.

Religious Education Council of England and Wales. 1982. RE Directory of England and Wales. Lancaster: REC.

Religious Education Council of England and Wales. 1984. Religious Education Provision for England and Wales. Lancaster: REC.

Religious Education Council of England and Wales. 1986. Memorandum on RE Provision for Minister of State for Education. Lancaster: REC.

Religious Education Council of England and Wales. 1987. Memorandum to Secretary of State for Education on the effective delivery of religious and moral education in the national curriculum. Lancaster: REC.

Religious Education Council of England and Wales. 2013. A Review of Religious Education in England.

London: REC.

Tatlow, T. 1945. 'William Temple.' Religion in Education 12:2: 31-34

Temple, W. 1936. 'Teachers and the Need of Our Time.' Religion in Education 3(4): 181-83.

Yeaxlee, B. 1934. 'The way forward', Religion in Education 1(3): 121-122.

Yeaxlee, B. 1934a. 'Madam How and Lady Why.' Religion in Education 1(2): 61-62.

Yeaxlee, B. 1934b. 'How Teachers May Equip Themselves.' Religion in Education 1(4): 190-196.

Yeaxlee, B. 1935. 'The realms of gold.' Religion in Education 2(3): 121-122.

Yeaxlee, B. 1936. 'The call for specialists.' Religion in Education 3(2): 61-62.

Yeaxlee, B. 1937a. 'From one quarter to another.' Religion in Education 4(1): 1-2.

Yeaxlee, B. 1942. 'Editorial: The dual system: A cross-bench view.' Religion in Education 9(3): 90-94.

Yeaxlee, B 1944. 'Editorial: The Butler Act in Practice.' Religion in Education 12(1): 1-4.

Yeaxlee, J. 1945. 'Religious drama; the new road to Damascus.' Religion in Education 13(1): 25-26. 